\title{
Sucrase-Isomaltase Is an Adenosine 3',5'-Cyclic Monophosphate-Dependent Epithelial Chloride Channel
}

\author{
ARTHUR L. FINN, ${ }^{*}$ ELDO V. KUZHIKANDATHIL, ${ }^{\dagger}$ GERRY S. OXFORD, ${ }^{\ddagger}$ and \\ YOSHI ITOH-LINDSTROM* \\ Departments of *Medicine and ${ }^{\ddagger}$ Cell and Molecular Physiology, University of North Carolina School of Medicine, Chapel Hill, North Carolina
}

See editorial on page 299.

Background \& Aims: We previously isolated a monoclonal antibody against a Necturus gallbladder epitope that blocks native adenosine $3^{\prime}, 5^{\prime}$-cyclic monophosphate (cAMP)-dependent chloride channels in intestine, gallbladder, urinary bladder, and airway epithelia in various animals. Methods: Using this antibody, we purified a 200-kilodalton protein that, when reconstituted in lipid bilayers, forms 9-pS chloride channels that are blocked by the antibody. Results: Amino acid sequencing of the purified protein showed strong homology to rabbit sucrase-isomaltase, an abundant intestinal enzyme. Western blot analysis of the in vitro-translated sucrase-isomaltase was indistinguishable from that of the protein used in the lipid bilayer studies. Expression of this protein in Chinese hamster ovary cells and in Xenopus laevis oocytes yielded CAMP-dependent chloride currents that in the latter system were blocked by the antibody. Conclusions: Because the monoclonal antibody blocks cAMP-dependent currents in epithelia as well as those produced both by the reconstituted and by the heterologously expressed protein, sucrase-isomaltase is a cAMPdependent epithelial chloride channel. Thus an enzyme that can also function as an ion channel has been described for the first time.

$\mathrm{M}$ any epithelia contain adenosine $3^{\prime}, 5^{\prime}$-cyclic monophosphate (cAMP)-dependent chloride channels in their apical membranes. ${ }^{1-3}$ When the channels open, chloride is secreted into the lumen of the particular organ such as the respiratory tree or the gastrointestinal tract. This channel is extremely abundant in the apical membrane of the gallbladder of Necturus maculosus ${ }^{4,5}$; making use of that fact, we immunized mice with these cells. We then obtained and purified a monoclonal antibody ( $\mathrm{mAb}$ E12) that fully blocks such chloride currents in epithelial cells from mudpuppies to humans and recognizes a protein of approximately 200 kilodaltons (p200). ${ }^{6}$ Reconstitution of the purified protein in lipid bilayers yields a
9-pS chloride channel that requires phosphorylation for activity and is blocked by the antibody. ${ }^{6-8}$

In the present study, we used the antibody to purify p200. We show that this protein demonstrates strong homology to a common enzyme, rabbit sucrase-isomaltase (SI). We also show that SI is a cAMP-dependent chloride channel when expressed in heterologous cells.

\section{Materials and Methods}

\section{Protein Purification}

We scraped the cells from the colons of 100 mudpuppies (we have previously shown that this protein is present in colon cells ${ }^{6}$ ) into ice-cold Necturus Ringer's solution containing protease inhibitors $(1 \mathrm{mmol} / \mathrm{L}$ phenylmethylsulfonyl fluoride, $10 \mathrm{mg} / \mathrm{mL}$ aprotinin, $0.1 \mathrm{mmol} / \mathrm{L}$ leupeptin, and $1 \mathrm{mmol} / \mathrm{L}$ pepstatin), homogenized for 1 minute in a VirTis homogenizer (VirTis, Gardiner, NY) and centrifuged at $40,000 \mathrm{~g}$ for 20 minutes. The supernatant was rotated overnight at $4^{\circ} \mathrm{C}$ in 10 $\mathrm{mmol} / \mathrm{L}$ CHAPS and separated into fractions on Sephacryl S-200-HR (Sigma, St. Louis, MO). Fractions were monitored for protein concentration and for the presence of p200 by mAb E12. An immunoaffinity column was prepared using Affi-Gel 10 gel (Bio-Rad, Hercules, CA) and mAb E12, according to the manufacturer's instructions. The fractions containing p200 were pooled, dialyzed overnight at $4^{\circ} \mathrm{C}$ against Tris-buffered saline-CHAPS ( $\mathrm{pH} 8.5$ ), then mixed gently overnight, again at $4^{\circ} \mathrm{C}$, with the immunoaffinity resin prepared as above. In the morning, the resin was put into a column and allowed to settle. The eluate was passed over the column several more times, and p200 was eluted with $0.2 \mathrm{~mol} / \mathrm{L}$ glycine- $\mathrm{HCl}(\mathrm{pH}$ 2.5).

\section{Plasmid Preparation}

The complementary DNA (cDNA) encoding SI was cut from its vector (pUC13) with SmaI and subcloned into the

Abbreviations used in this paper: CFTR, cystic fibrosis transmembrane conductance regulator; $\mathrm{CHO}$, Chinese hamster ovary; PCR, polymerase chain reaction; RT, reverse transcription; SI, sucrase-isomaltase. (C) 2001 by the American Gastroenterological Association 0016-5085/01/\$10.00 doi:10.1053/gast.2001.20884 
expression vector pcDNA3.0 (Invitrogen, Carlsbad, CA). The plasmid was purified in a large-scale preparation by alkaline lysis followed by equilibrium centrifugation in a $\mathrm{CsCl}-$ ethidium bromide gradient. 9 Identity with the published sequence of rabbit SI was confirmed by sequencing and restriction enzyme digestion. The cDNA included the entire open reading frame of SI, but a part of the $3^{\prime}$-untranslated end was not included.

\section{Cell Culture and Transfection}

Chinese hamster ovary $(\mathrm{CHO})$ cells were grown in Ham's F12 medium with $10 \%$ fetal calf serum and 10,000 U of penicillin/streptomycin. For transient transfections and subsequent electrophysiologic characterization, cells were plated onto glass coverslips coated with $40 \mathrm{mg} / \mathrm{mL}$ poly-L-lysine. Cells were transiently transfected using Lipofectamine (GIBCO-BRL, Grand Island, NY) with expression plasmids encoding the green fluorescent protein (pEGFP-N2; Clontech, Palo Alto, CA) and the full-length SI (pcSI, obtained by subcloning SI into the mammalian expression vector pcDNA3 [Invitrogen]). Expression efficiency of $15 \%-30 \%$, assessed by the green fluorescent protein marker, was routinely achieved.

\section{Electrophysiology: CHO Cells}

Patch electrodes were pulled from cleaned Drummond N51A glass (Drummond Scientific Co., Broomall, PA) on a PP-83 (Narashige, Tokyo, Japan) puller. Electrodes were polished at $800 \times$ on a homemade microforge. Electrode tips were filled by dipping into a simple chloride salt solution of the major cation for an experiment (e.g., $\mathrm{KCl}, \mathrm{HEPES}, \mathrm{MgCl}_{2}$ ) and then back-filled with the desired patch solution (Table 1). Electrodes were positioned using Newport (Newport Corp. Irvine, CA) mechanical/motorized manipulators. The experimental chamber containing cells was viewed with a Nikon Diaphot (Nikon Inc., Melville, NY) inverted microscope at $400 \times$ under Hoffman optics and is continuously superfused at $1 \mathrm{~mL} / \mathrm{min}$ with external solutions. Whole-cell macroscopic

Table 1. Solutions

\begin{tabular}{lrrrrcrr}
\hline & $\mathrm{HCl}$ & $\mathrm{LCl}$ & $\mathrm{HCE}$ & LCE & OR & ND96 & OCND \\
\hline $\mathrm{NaCl}$ & 0 & 0 & 145 & 0 & 86 & 96 & 96 \\
$\mathrm{Nalseth}$ & 0 & 0 & 0 & 145 & 0 & 0 & 0 \\
$\mathrm{KCl}$ & 145 & 5 & 5 & 0 & 1.5 & 2 & 2 \\
$\mathrm{Kasp}$ & 0 & 140 & 0 & 0 & 0 & 0 & 0 \\
$\mathrm{MgCl}_{2}$ & 1 & 1 & 1 & 1 & 1 & 1 & 1 \\
$\mathrm{CaCl}_{2}$ & 0 & 0 & 2 & 2 & 0 & 1 & 0 \\
$\mathrm{EGTA}$ & 1 & 1 & 0 & 0 & 0 & 0 & 1 \\
$\mathrm{HEPES}$ & 10 & 10 & 10 & 10 & 10 & 10 & 10 \\
$\mathrm{Glucose}^{-}$ & 10 & 10 & 10 & 10 & 0 & 0 & 0 \\
$\mathrm{Cl}^{-}$ & 147 & 7 & 156 & 6 & 89.5 & 102 & 100 \\
\hline
\end{tabular}

NOTE. All concentrations are given in mmol/L. OR and ND96 also contained $50 \mathrm{mg} / \mathrm{mL}$ gentamycin. $\mathrm{HCl}$, high-chloride internal (pipette) solution; LCl, low-chloride internal (pipette) solution; HCE, high-chloride external solution; LCE, low-chloride external solution; OR, Oocyte Ringer; OCND, zero calcium ND $=96$. currents were sampled with a Digidata 1200b interface (Axon Instruments, Inc., Foster City, CA) using Axotape and pClamp 7.0 software (Axon Instruments). Currents were elicited by ramp voltage commands $(-120 \mathrm{mV}$ to $+40 \mathrm{mV})$ of 800 milliseconds' duration from a holding potential of -60 .

\section{Electrophysiology: Xenopus laevis Oocytes}

Oocytes are surgically removed and placed in OR medium (Table 1). The follicular cell layer is removed by incubating the oocytes for 2-3 hours in $\mathrm{Ca}^{2+}$-free OR medium containing $1.5 \mathrm{mg} / \mathrm{mL}$ collagenase (170 U/mg; GIBCO-BRL), and stored in ND-96 medium at $18^{\circ} \mathrm{C}$ for 24 hours before RNA injection. For these studies, purified plasmid DNA (either pcSI, prepared as described above, or human cystic fibrosis transmembrane conductance regulator (CFTR) DNA, kindly provided by Dr. David Dawson, subcloned into the plasmid vector pBluescript [Stratagene, La Jolla, CA]) was used as the template for the synthesis of capped RNA using the Message Machine kit (Ambion, Austin, TX). Template DNA was removed by RNase-free DNase I, and the RNA was extracted with phenol/chloroform, precipitated in isopropyl alcohol, and resuspended in RNase-free TE buffer (10 mmol/L Tris-Cl plus $1 \mathrm{mmol} / \mathrm{L}$ EDTA, pH 8). RNA was examined on ethidium bromide-stained denaturing agarose minigels and showed a single undegraded band of the correct size. Each oocyte was injected with $46 \mathrm{~nL}$ containing $25 \mathrm{ng}$ RNA in $100 \mathrm{mmol} / \mathrm{L} \mathrm{KCl} \mathrm{using} \mathrm{a} \mathrm{Drummond} \mathrm{Nanojector.}$ Control oocytes were injected with like volumes of 100 $\mathrm{mmol} / \mathrm{L} \mathrm{KCl}$, water, or empty vector. For study, cells were placed in a chamber in zero calcium ND $=96$ medium 2 days later, and data were obtained using the 2-electrode voltage clamp method.

\section{Reverse-Transcription Polymerase Chain Reaction}

Total RNA was isolated from mudpuppy gallbladder, urinary bladder, small intestine, colon, liver and skeletal muscle using Trizol reagent (Molecular Research Center, Cincinnati, OH) according to the manufacturer's protocol. Firststrand cDNA was synthesized using reverse transcriptase (RT; Life Technologies, Grand Island, NY); polymerase chain reaction (PCR) was performed using PlatinumTaq DNA polymerase (Life Technologies) in a Perkin-Elmer 9600 thermocycler (PerkinElmer Instruments Inc., Boston, MA). The primers used were for sucrase, 5'-GAACCCTCGAGCACCTGAATG-3' (forward), 5' TGGGCATTTCCTTCATCTTCC-3' (reverse); for $\beta$-actin, $5^{\prime}$ GGCATTGTTACCAACTGGGAC-3' (forward), 5'-ACCAGAGGCATACAGGGACAG-3' (reverse). These primers led to a predicted fragment length of 588 base pairs (bp) for SI and $219 \mathrm{bp}$ for actin. PCR conditions were predenaturation at $94^{\circ} \mathrm{C}$ for 4 minutes, followed for sucrase by 40 cycles of denaturation at $94^{\circ} \mathrm{C}$ for 1 minute, annealing at $60^{\circ} \mathrm{C}$ for 30 seconds, and elongation at $72^{\circ} \mathrm{C}$ for 1 minute. For actin, the annealing temperature was $65^{\circ} \mathrm{C}$, and we used 35 cycles. 


\section{Results}

The protein immunopurified from mudpuppy colon contained a single band when viewed by silverstained polyacrylamide gel electrophoresis. A sample was run onto a gel, stained with Coomassie blue, then cut out of the gel, destained, washed with $50 \%$ acetonitrile, frozen, and sent to the Harvard microsequencing facility to obtain sequence information. Analysis yielded 2 nonoverlapping peptides with 19 of 20 amino acids identical to rabbit SI (Figure 1), a protein first cloned in 1986, ${ }^{10}$ and no significant similarity to any other protein in the data banks. Because of this observation, we obtained rabbit SI cDNA from Dr. Ned Mantei of the Swiss Federal Institute of Technology in Zurich.

To determine if the antibody that recognizes p200 also recognizes SI, we performed in vitro transcription and translation of SI, as previously described. ${ }^{11,12}$ We used a coupled reticulocyte lysate assay system (Promega, Fitchburg, WI), ran the resulting product on sodium dodecyl sulfate-polyacrylamide gel electrophoresis, and transferred it to nitrocellulose for a Western blot assay using $\mathrm{mAb}$ E12. As shown in Figure 2, the translation product reacts with the monoclonal antibody exactly as does an aliquot of the purified protein that had been sent for the sequence analysis, suggesting that SI and p200 are the same protein.

The cDNA encoding SI was subcloned into the mammalian expression vector pcDNA3.0 and transfected into $\mathrm{CHO}$ cells (Figure 3). Electrophysiologic studies of transfected and control (nontransfected) cells were carried out 2-3 days later. The results are shown in Figure $3 A-D$ and summarized in Figure $3 E$. In each of the 14 pcSI-transfected cells, there was an increase in current, most marked at hyperpolarizing potentials, after the elevation in intracellular cAMP (Figure 3). There are no known sodium currents in the membrane under these conditions, so that the increase in current can be explained only by potassium entry into the cells or chloride exit from them (at hyperpolarizing potentials; the reverse is true at depolarizing potentials). However, because there is a highly significant shift of the reversal potential (depolarization of $24.4 \pm 3.8 \mathrm{mV}$ ) away from the potassium equilibrium potential $(-85 \mathrm{mV})$ and toward that

\section{Peptide \#1: $\quad$ LPSNYIYGFGE}

Rabbit SI: QISTRLPSEYIYGFGEAEHTAFKRDLNWHT 1130

\section{Peptide \#2: $\quad$ WTQLGAFYP}

Rabbit SI: GFFNDSEYHLCTRWTQLGAFYPFARNHNI 1560

Figure 1. Primary structure of the 2 peptide sequences and of the corresponding portions of rabbit SI. Shaded amino acids are identical in the 2 structures.

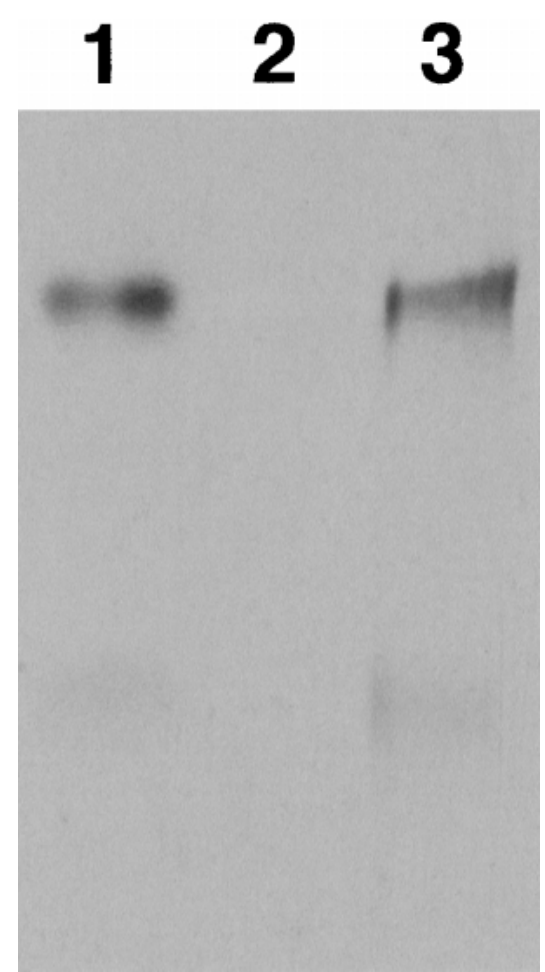

Figure 2. In vitro translation of pcSI yields a protein identical to p200. Western blot analysis was performed with mAb E12. Lane 1 was loaded with $15 \mathrm{ng}$ of purified p200, lane 2 with unpurified translation product without added DNA, and lane 3 with unpurified translation product from a reaction that contained added pcSI. According to the manufacturer, the volume we loaded onto the gel contained somewhere between 10 and $40 \mathrm{ng}$ of translated protein. Upper bands, 200 kilodaltons; lower bands, 105 kilodaltons. We presume that the lower band is a degradation product because it usually is not seen in fresh material.

for chloride $(-1 \mathrm{mV})$, these currents are most likely carried by chloride. A clear representation of this is shown in Figure $3 C$, in which the subtracted current voltage (IV) curve shows a reversal potential near the origin, as expected for a chloride current, when the transmembrane chloride gradient is close to zero (147 $\mathrm{mmol} / \mathrm{L}$ intracellular, $156 \mathrm{mmol} / \mathrm{L}$ extracellular; Table 1). Confirmation was obtained by changing the transmembrane chloride concentration gradient. In one series of experiments $(\mathrm{n}=3)$ in which internal chloride was 7 $\mathrm{mmol} / \mathrm{L}$ and external chloride was $156 \mathrm{mmol} / \mathrm{L}$, elevation of cellular cAMP caused hyperpolarizing shifts of $-12.0 \pm 2.3 \mathrm{mV}$, again in the direction expected for a chloride channel (in these cells, both internal and external $\mathrm{K}^{+}$were $5 \mathrm{mmol} / \mathrm{L}$ ). In another group of 3 cells in which internal chloride was $147 \mathrm{mmol} / \mathrm{L}$ and external chloride was $6 \mathrm{mmol} / \mathrm{L}$ (a high outward gradient for both chloride and potassium), the addition of the cAMP cocktail induced a depolarizing shift of $34.7 \pm 1.8 \mathrm{mV}$, again indicating the opening of chloride channels. Finally, in one cell in which the pipette chloride concentration was 

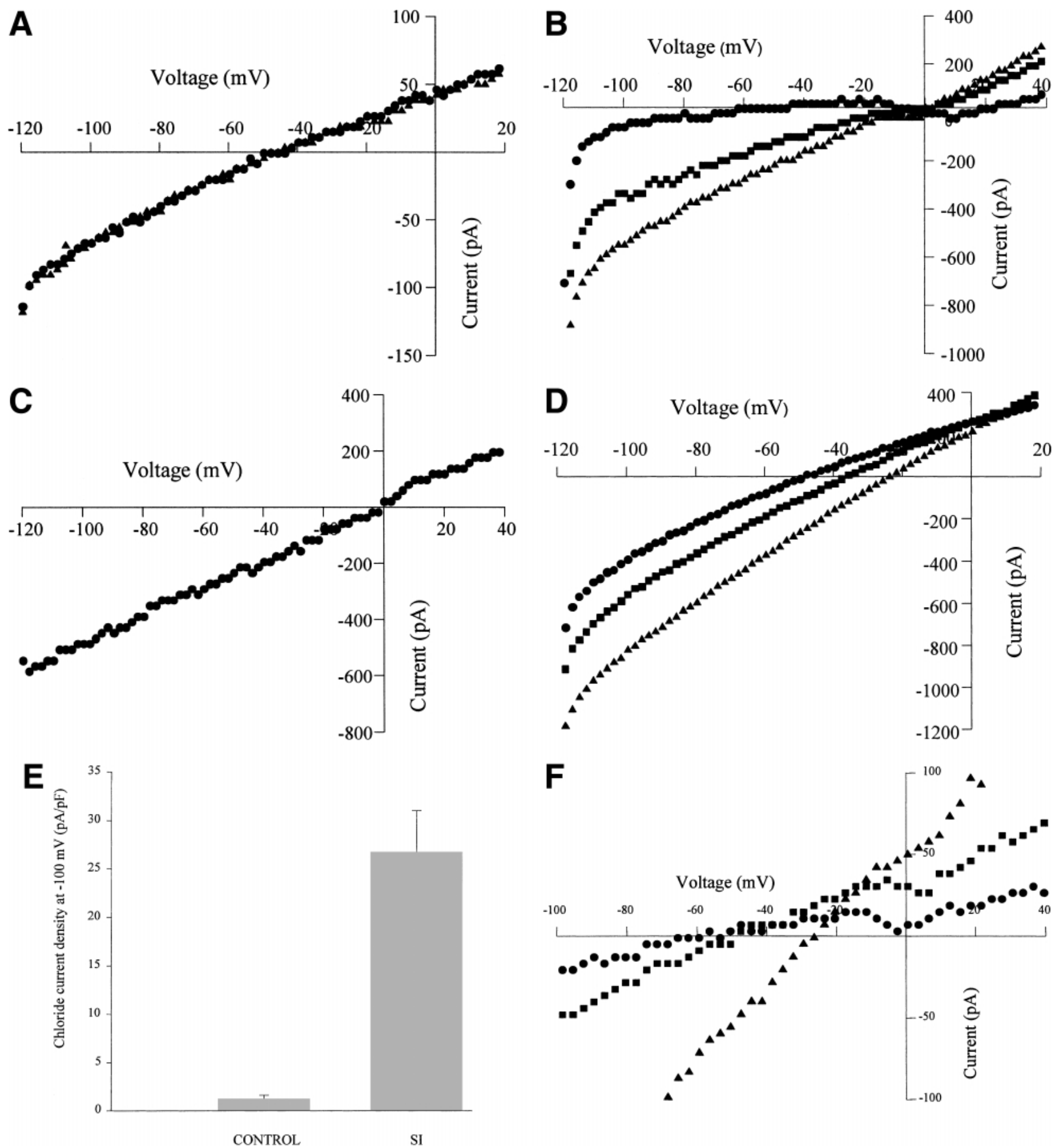

Figure 3. Voltage-clamped currents in $\mathrm{CHO}$ cells. Except as described below, the external medium is $\mathrm{HCE}$ (Table 1), the internal $\mathrm{HCl}$ (essentially 0 transmembrane chloride gradient: $\left.\mathrm{Cl}_{\text {in }}=147, \mathrm{Cl}_{\text {out }}=156\right)$. During cAMP periods, a combination of $2 \mathrm{mmol} / \mathrm{L}$ theophylline and $1 \mathrm{mmol} / \mathrm{L} 8$-bromo cAMP (the cAMP cocktail) was added to the external solution. $(A)$ Nontransfected cells have no cAMP-dependent current. In this control cell, 2 sets of currentvoltage data are displayed, one obtained before $(\boldsymbol{\bullet})$ and one 5 minutes after $(\boldsymbol{\Lambda})$ the addition of the cAMP/theophylline mixture. The data are superimposable. (B) Transfection with pcSI leads to the appearance of a cAMP-dependent current. Its speed of onset is shown by the 2 sets of IV curves,

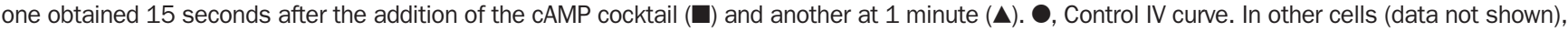
the current was shown to be stable by approximately 1 minute. $(C)$ cAMP-dependent current was obtained by subtraction of the baseline (control) IV curve from the curve obtained 1 minute after addition of the cocktail in Figure 2B. (D) Reversibility of cAMP-dependent current. In this transfected cell, we show traces before addition of the cAMP mixture $(\boldsymbol{\square})$ and after its removal $(\mathbf{O})$. $\mathbf{\Delta}$, cAMP-induced current. There are approximately 2 minutes between traces. $(E)$ Summary of results in $\mathrm{CHO}$ cells. The ordinate shows the cAMP-dependent current density $( \pm \mathrm{SEM})$ when the membrane voltage was clamped at $-100 \mathrm{mV}$. The difference in current levels between control $(\mathrm{n}=7)$ and transfected $(\mathrm{n}=14)$ cells is highly significant $(P<0.01)$. $(F)$ Effect of changes in chloride gradient. In this transfected cell, the pipette contains $\mathrm{HCl}$. $\bullet$, Control IV data (with LCE in the bath, $\mathrm{HCl}$ in the pipette). Upon addition of the cAMP cocktail, with the same external medium, the IV data show a typical response $(\mathbf{\Delta})$. Upon increasing external chloride $\left(\mathrm{HCE}_{\text {out }}, \mathrm{HCl}_{\text {in }}\right)$, i.e., decreasing the transmembrane gradient (in the continued presence of cAMP [ $\mathbf{\square}]$ ), there was a shift of the reversal potential back to control levels. 
$147 \mathrm{mmol} / \mathrm{L}$, we switched the external chloride concentration from $6 \mathrm{mmol} / \mathrm{L}$ to $156 \mathrm{mmol} / \mathrm{L}$ during cAMP stimulation, thus decreasing the chloride gradient (Figure $3 F$ ). It can be seen that the reversal potential shifted once again toward the new chloride equilibrium potential when the chloride gradient decreased. In similar experiments with AtT-20 cells (not shown), transfection with pcSI also invariably led to the expression of a cAMP-dependent current that was not observed in nontransfected cells. Thus, in mammalian cells expressing SI, a robust cAMP-induced chloride current can be detected. Untransfected control cells examined under similar conditions do not exhibit any such currents (Figure $3 E)$.

We also studied the expression of the SI cDNA in Xenopus laevis oocytes, a system that allows relatively long-term experiments in which a single cell can be used as its own control. Consistent with a previous report, ${ }^{13}$ we found no cAMP-dependent current in 5 control (KClor water-injected) oocytes (data not shown). Oocytes injected with in vitro-transcribed SI RNA (Figure $4 A-F)$ showed, in every cell examined, a significant cAMP-dependent increase in membrane current that was fully reversible upon removal of the 8-bromo-cAMP/ theophylline cocktail. Furthermore, these cAMP-dependent currents were fully blocked by mAb E12. As an additional control, we injected capped RNA prepared from CFTR DNA into other oocytes. Results (data not shown) were virtually identical to those previously described $^{13}$; however, mAb E12 had no effect on the cAMP-dependent chloride current, in contrast to its inhibitory effect after SI expression.

To determine the expression of SI in the mudpuppy, we performed RT-PCR using primers from the sucrase portion of rabbit cDNA. As shown in Figure 5, message is present in all tissues studied, although the level of expression is lower in muscle than in the other organs studied.

\section{Discussion}

Our results indicate that the abundant intestinal enzyme SI can also function as an epithelial chloride channel. The idea that a single protein can have more than a single function is not new ${ }^{14-16}$; in fact, SI has also been shown to be a Clostridium difficile toxin A-binding site in rabbit ileum. ${ }^{17}$ It is interesting that in all the other cases described so far, the multiple activities are neither independent nor disparate in their functions. For example, ${ }^{16}$ in paramecium a potassium channel controls the activity of adenylyl cyclase. In this case, both activities are contained in the same protein, and the channel activity and the enzyme activity are strictly interdependent. One could argue ${ }^{18}$ that many types of receptors are bifunctional in the sense, for instance, of ligand-gated ion channels, which are at the same time receptors and ion channels. However, there is no precedent for the apparent independence of the functions attributable to SI.

There seems to be no obvious physiologic advantage to be derived from having 2 such apparently disparate functions combined in a single protein, other than the obvious one of parsimony (for example, why "waste" a transmembrane domain as "simply" an anchor for a luminal enzyme?) because it is evident that the protein acts as a channel in far more organs than it acts as an enzyme. Further studies are needed to clarify the relationship between the 2 major functions of the protein in both physiologic and pathophysiologic (such as secretory diarrhea, cystic fibrosis, or sucrase deficiency) conditions.

We have previously shown that mAb E12 blocks all cAMP-dependent current in mudpuppy and toad gallbladder, rat colon, cultured human nasal epithelial cells, ${ }^{6}$ and mouse colon (Finn AL, unpublished observations), suggesting that this chloride channel is also quite abundant. Indeed, in the mudpuppy gallbladder, this channel must make up a sizable fraction of total apical membrane protein because an increase in cellular cAMP can increase total membrane conductance up to 200-fold, all of which is caused by the appearance of a chloride current that is fully blocked by mAb E12.4,5

Is it possible that rather than forming a channel itself, expression of SI in mammalian cells or oocytes unmasks or stimulates a native chloride channel preexisting in the cell? We believe this alternative to be unlikely in view of strong evidence from 2 sources. First, reconstitution of the purified protein (an aliquot of the same protein that was sequenced) in lipid bilayers has in every case yielded highly selective chloride channels. ${ }^{6-8}$ These channels have identical kinetic characteristics despite a 5-10-fold dilution of the protein, reducing the likelihood that an undetectable impurity might be the channel molecule. Second, the channel is blocked by the antibody, whether it is reconstituted in lipid bilayers ${ }^{6,8}$ or expressed in Xenopus oocytes, whereas CFTR channels are not blocked by the antibody. It is also unlikely that the expression of SI in the heterologous systems described above could be accounted for by "piggybacking" of another protein on SI because at least 2 major characteristics of the expression seen in Figures 3 and 4 (the requirement of phosphorylation and the blockade by $\mathrm{mAb}$ E12) are similar to those seen in the bilayer expression system. 

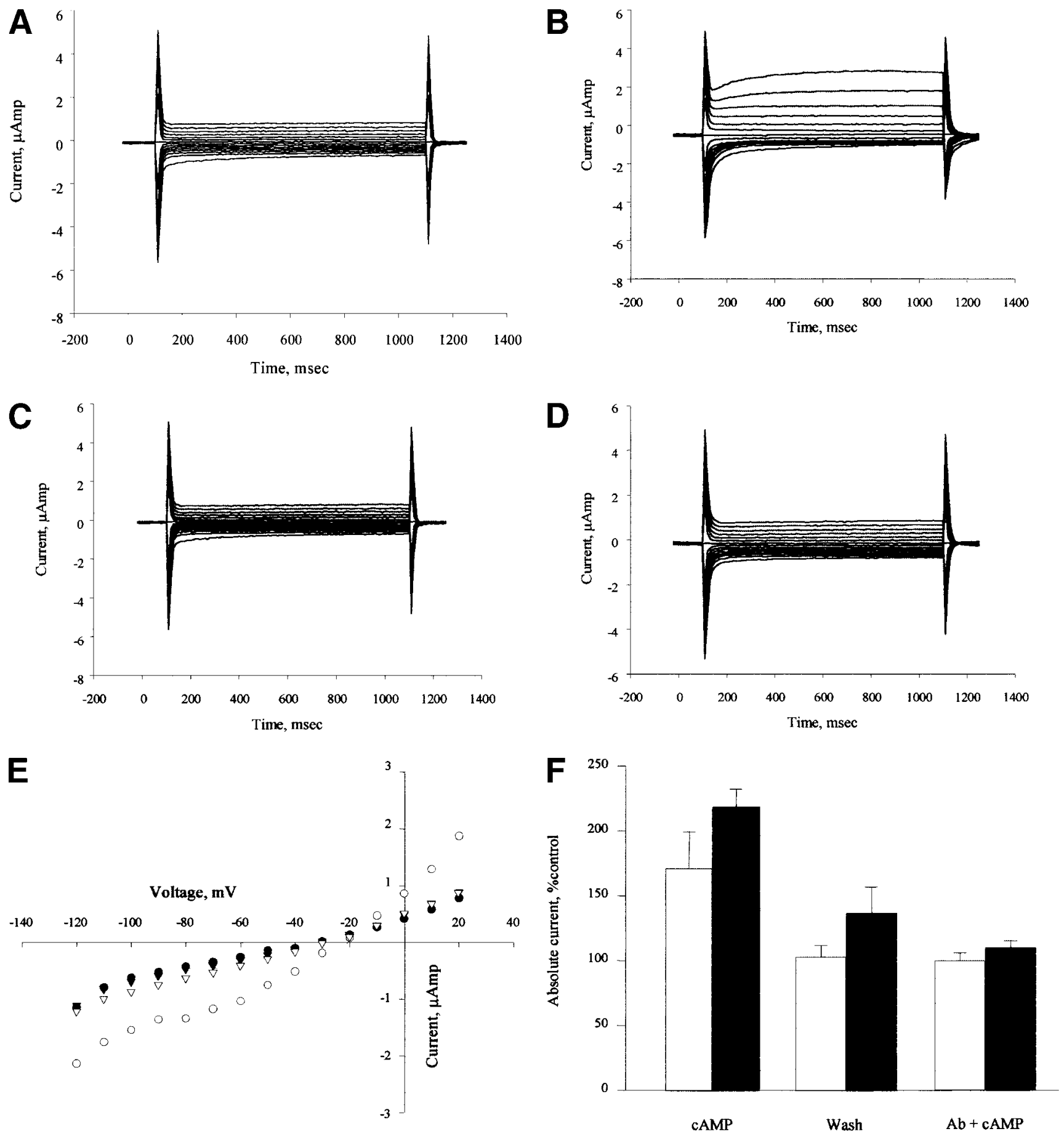

Figure 4. Voltage-clamped currents in Xenopus laevis oocytes. We studied only oocytes in which the initial resting membrane potential was greater than $-25 \mathrm{mV}$; otherwise, the cells were not selected. Cells were clamped at a membrane potential of $-40 \mathrm{mV}$, and at 5 -minute intervals a series of 15 12-second voltage clamp steps was applied, $10 \mathrm{mV}$ apart, from -120 to $+20 \mathrm{mV}$. In every case, the RNA-injected cells showed a sustained response to elevation of cell cAMP; the response began in each case by 5 minutes and increased to a maximum 10-15 minutes after addition of the cocktail. Washout of the response followed a similar time course, reaching baseline values within 15 minutes after removal of the cocktail. None of the $\mathrm{KCl}-$, water-, or empty vector (pcDNA 3.0)-injected cells showed any response either to cAMP elevation or to antibody. Traces from a single RNA-injected cell are shown $(A)$ before and $(B) 15$ minutes after addition of the cAMP cocktail, then $(C) 15$ minutes after removal of the cocktail and $(D) 15$ minutes after the antibody and the cocktail were added again. The antibody completely prevents the response to stimulation. In one cell, we added and removed cAMP 3 times, and each time there was an identical response. $(E)$ Current-voltage curves obtained 50 milliseconds after the start of the pulse, from the data shown in A-D. The cAMP-dependent increase is evident and includes a shift in the reversal potential toward the chloride equilibrium potential. $\bullet$, Control responses; $\bigcirc$, responses after cAMP elevation; $\mathbf{\Delta}$, responses after washout of the cocktail; $\triangle$, responses after antibody + cAMP cocktail. We chose to plot the data at 50 milliseconds purely arbitrarily; at 1 second, the control current in this oocyte was $-600 \mathrm{nA}$ at $-120 \mathrm{mV}$. In the other 3 , the control currents at that voltage and time were $-130,-50$, and $-90 \mathrm{nA}$. $(F)$ Mean responses ( \pm SEM) of 4 injected oocytes; $\square$, data obtained at $-120 \mathrm{mV}$ 口, data obtained at $+20 \mathrm{mV}$. The changes after cAMP alone are significantly different from control currents $(P<0.01)$, and none of the other changes (after wash or after antibody plus the cAMP cocktail) is significant. 


\section{(-) GB UB SI Col Liv Mus}

\section{Sucrase}

\section{Actin}

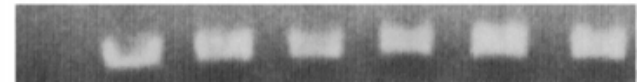

Figure 5. Sucrase gene expression analysis by RT-PCR. Total RNA was isolated from the gall bladder (GB), urinary bladder (UB), small intestine (SI), colon (Col), liver (Liv), and muscle (Mus). First-strand cDNA was synthesized, and PCR was performed as described in Materials and Methods. (-), negative control. Major fragment sizes are as predicted.

As noted above, mAb E12 does not affect cAMPdependent chloride currents in Xenopus oocytes injected with CFTR message. Furthermore, as shown previously and by the present data, it is clear that this monoclonal antibody recognizes SI, a protein entirely different from CFTR. Finally, mAb E12 blocks all cAMP-dependent current in all of the epithelia so far tested. 4,6 Because it has been presumed that much or all of the epithelial cAMP-dependent chloride current is caused by CFTR channels, the current data at least raise questions about this interpretation. There is no specific inhibitor of epithelial CFTR, as there is of SI chloride channels, yet both have now been expressed in heterologous systems. It is not entirely surprising that simultaneous expression of both in oocytes showed only apparent independence because the steps from message injection to membrane expression are multiple and complicated. Studies are now being directed at the possible relationship between these 2 important proteins.

What kind of protein is SI? Hydropathy analysis suggests that it has but one transmembrane domain in its primary structure. ${ }^{10}$ One native channel described with that topology is $\operatorname{minK},{ }^{19}$ but it has recently been shown to associate with other channel subunits to form functional channels. ${ }^{20}$ Of more interest is phospholemman, a 72-amino acid protein with a single transmembrane domain $^{21,22}$; this protein conducts a large number of ions and induces a chloride current in Xenopus oocytes. However, it has no sequence homology or structural resemblance to SI.

It should be noted that it was the astounding homology of P200 to the already-cloned SI that induced us to obtain the SI cDNA and study it, and not a preconceived notion. The distribution of SI has been studied extensively, although it is unfortunate that until now there have been no studies of expression of this protein in the upper airways, gallbladder, or urinary bladder, all of which show SI by Western blot analysis using our monoclonal antibody. ${ }^{6}$ Northern blots have shown message in the small intestines of mammals and none in the normal colon. ${ }^{23}$ However, other studies with $\mathrm{mAbs}$ have clearly shown that SI is present in normal human colon ${ }^{24,25}$; in addition, the enzyme is abundant in both benign ${ }^{25,26}$ and malignant ${ }^{26}$ tumors of the colon, so that our finding of extensive colon expression of SI (using mAb E12) is not inconsistent with that observed for SI thus far. SI enzyme activity has not been found in the frog Rana pipiens, although there is but a single study, ${ }^{27}$ and in the experiments described sucrose placed in the intestinal lumen did not lead to measurable glucose absorption. Because SI (that is, a protein that reacts with $\mathrm{mAb}$ E12 and has high homology with rabbit SI) is clearly present in the amphibian (mudpuppy gallbladder, colon, and urinary bladder, toad gallbladder, and urinary bladder; Tsai et al. $\left.{ }^{6}\right)$, the explanation for the negative findings in frog intestine is most likely attributable to a lack of sensitivity in those experiments. Consistent with this is our finding, by the more sensitive method RT-PCR, of SI message in all mudpuppy organs tested. These include colon, urinary bladder, and gallbladder, in which we have also shown functional activity (i.e., cAMP-dependent chloride currents blocked by antibody). The apparent ubiquity of message is not unlike that of CFTR message, which has been found in many tissues other than those known or thought to be principally affected in cystic fibrosis (airways, pancreas, sweat glands, epididymis, intestine), such as gallbladder, ${ }^{28,29}$ heart, ${ }^{30,31}$ uterus, ${ }^{32,33}$ brain, ${ }^{34,35}$ endothelial cells, ${ }^{36}$ and liver. ${ }^{37}$

Wells and Hediger ${ }^{38}$ and Bertran et al. ${ }^{39}$ have described an amino acid transporter with a single transmembrane domain, but no other transporters with this characteristic have yet been defined. Furthermore, a search of protein databanks shows no significant homologies of SI with any known transporter. The putative transmembrane domain in SI contains only neutral amino acids but clearly is highly selective for anions. Because this channel is stimulated by cAMP, the likelihood that the transmembrane domain alone forms channels is small, especially given its structure. In this regard, we are planning to study the behavior of the transmembrane domain expressed alone as well as of the protein without the transmembrane domain.

Given the present state of our knowledge of membrane ion channels, it would appear likely that the transporting form of the molecule is a multimer of some sort, but this is by no means proven. At the very least, the idea that such a protein can be a channel capable of carrying chloride currents challenges current views of ion channel structure-function relationships. Furthermore, the concept that a single protein can have 2 such apparently 
disparate and unrelated functions is unprecedented. Indeed, from our previous findings that respiratory and urinary (as well as intestinal) epithelia contain SI chloride channels, ${ }^{6}$ one wonders about the regulation of an enzyme that exists in a variety of epithelia that never see its substrate. This information raises the basic question of whether the enzyme and channel functions are completely independent; studies are currently under way to evaluate this.

The importance of the antibody in these studies cannot be minimized. As previously shown, it has no evident action other than recognizing and blocking the function of this channel protein ${ }^{6}$; that is, it has no effect on sodium, potassium, or water transport or on baseline electrophysiologic properties of the mudpuppy gallbladder. Whether it affects the enzymatic function of SI remains to be seen; this question has considerable importance in the study of the relative independence of the 2 main functions of this protein.

\section{References}

1. Anderson MP, Sheppard DN, Berger HA, Welsh MJ. Chloride channels in the apical membrane of normal and cystic fibrosis airway and intestinal epithelia. Am J Physiol 1992;263:L1-L14.

2. Frizzell RA, Rechkemmer, G, Shoemaker RL. Altered regulation of airway epithelial cell chloride channels in cystic fibrosis. Science 1986;233:558-560.

3. Light DB, Schwiebert EM, Fejes-Toth GA, Naray-Fejes-Toth A, Karlson KH, McCann FV, Stanton BA. Chloride channels in the apical membrane of cortical collecting duct cells. Am J Physiol 1990; 258:F273-F280.

4. Finn AL, Tsai L-M, Falk RJ. Monoclonal antibodies to the apical chloride channel in Necturus gallbladder inhibit the chloride conductance. Proc Natl Acad Sci U S A 1989;86:7649-7652.

5. Petersen K-U, Reuss L. Cyclic AMP-induced chloride permeability in the apical membrane of Necturus gallbladder epithelium. J Gen Physiol 1983;81:705-729.

6. Tsai L-M, Dillard M, Rosenberg RL, Falk RJ, Gaido ML, Finn AL. Reconstitution of an epithelial chloride channel, conservation of the channel from mudpuppy to man. J Gen Physiol 1991;98:723750 .

7. Finn AL, Dillard M, Gaido ML. Independently-gated multiple substates of an epithelial chloride-channel protein. Proc Natl Acad Sci U S A 1993;90:5691-5694.

8. Finn AL, Gaido ML, Dillard M, Brautigan DL. Regulation of an epithelial chloride channel by direct phosphorylation and dephosphorylation. Am J Physiol 1992;263:C172-C175.

9. Sambrook J, Fritsch FF, Maniatis T, eds. Molecular cloning. A laboratory manual. 2nd ed. Cold Spring Harbor, NY: Cold Spring Harbor Laboratory, 1989:1.33-1.40.

10. Hunziker W, Spiess M, Semenza G, Lodish HF. The sucraseisomaltase complex: primary structure, membrane-orientation, and evolution of a stalked, intrinsic brush border protein. Cell 1986;46:227-234.

11. Alpers DH, Helms D, Seetharam S, May VL, Strauss AW. In vitro translation of intestinal sucrase-isomaltase and glucoamylase. Biochem Biophys Res Commun 1986;134:37-43.

12. Ghersa P, Huber P, Semenza G, Wacker H. Cell-free synthesis, membrane integration, and glycosylation of pro-sucraseisomaltase. J Biol Chem 1986;261:7969-7974.

13. Cunningham SA, Worrell RT, Benos DJ, Frizzell RA. cAMP-stimu- lated ion currents in Xenopus oocytes expressing CFTR cRNA. Am J Physiol 1992;262:C783-C788.

14. Jiang LL, Kurosawa T, Sato M, Suzuki Y, Hashimoto T. Physiolog ical role of D-3-hydroxyacyl-CoA dehydratase/D-3-hydroxyacyl-CoA dehydrogenase bifunctional protein. J Biochem 1997;121:506513.

15. Kornfeld S. Structure and function of the mannose 6-phosphate/ insulinlike growth factor II receptors. Annu Rev Biochem 1992; 61:307-330.

16. Schultz JE, Klumpp S, Benz R, Schurhoff-Goeters WJC, Schmid A. Regulation of adenylyl cyclase from Paramecium by an intrinsic potassium conductance. Science 1992;255:600-603.

17. Pothoulakis C, Gilbert RJ, Cladaras C, Castagliuolo I, Semenza G, Hitti Y, Montcrief JS, Linevsky J, Kelly CP, Nikulasson S, Desai HP, Wilkins TD, LaMont TJ. Rabbit sucrase-isomaltase contains a functional intestinal receptor for Clostridium difficile toxin A. J Clin Invest 1996;98:641-649.

18. Maelicke A. An ion channel-gated adenylyl cyclase. Trends Biochem Sci 1992;17:51.

19. Kaczmarek LK, Blumenthal EM. Properties and regulation of the minK potassium channel protein. Physiol Rev 1997;77:627641.

20. McDonald TV, Yu Z, Ming Z, Palma E, Meyers MB, Wang KW, Goldstein SA, Fishman Gl. A minK-HERG complex regulates the cardiac potassium current I(Kr). Nature 1997;388:289-292.

21. Kowdley GC, Ackerman SJ, Chen Z, Szabo G, Jones LR, Moorman $J R$. Anion, cation, and zwitterion selectivity of phospholemman channel molecules. Biophys J 1997;72:141-145.

22. Moorman J R, Ackerman SJ, Kowdley GC, Griffin MP, Mounsey JP, Chen Z, Cala SE, O'Brian JJ, Szabo G, Jones LR. Unitary anion currents through phospholemman channel molecules. Nature 1995;377:737-740.

23. Leeper LL, Henning SJ. Development and tissue distribution of sucrase-isomaltase mRNA in rats. Am J Physiol 1990;258:G52G58.

24. Beaulieu J-F, Weiser MM, Herrera L, Quaroni A. Detection and characterization of sucrase-isomaltase in adult human colon and in colonic polyps. Gastroenterology 1990;98:1467-1477.

25. Gorvel JP, Ferrero A, Chambraud A, Rigal A, Bonicel J, Maroux S. Expression of sucrase-isomaltase and dipeptidylpeptidase IV in human small intestine and colon. Gastroenterology 1991;101: $618-625$.

26. Wiltz O, O'Hara CJ, Steele GDJr, Mercurio AM. Expression of enzymatically active sucrase-isomaltase is a ubiquitous property of colon adenocarcinomas. Gastroenterology 1991;100:12661278.

27. Parsons DH, Prichard JS. Hydrolysis of disaccharides during absorption by the perfused small intestine of amphibia. Nature 1965;208:1097-1098.

28. Dray-Charier N, Paul A, Veissiere D, Mergey M, Scoazec JY, Capeau J, Brahimi-Horn C, Housset C. Expression of cystic fibrosis transmembrane conductance regulator in human gallbladder epithelial cells. Lab Invest 1995;73:828-836.

29. Peters RHPC, French PJ, Van Doorninck JH, Lamblin G, Ratcliff R, Evans MJ, Colledge WH, Bijman J, Scholte BJ. CFTR expression and mucin secretion in cultured mouse gallbladder epithelial cells. Am J Physiol 1996;271:G1074-G1083.

30. Hume JR, Horowitz B. A plethora of cardiac chloride conductances: molecular diversity or a related gene family. J Cardiovasc Electrophysiol 1995;6:325-331.

31. James AF, Tominaga T, Okada Y, Tominaga M. Distribution of cAMP-activated chloride current and CFTR mRNA in the guinea pig heart. Circ Res 1996;79:201-207.

32. Hayslip CC, Hao E, Usala SJ. The cystic fibrosis transmembrane regulator gene is expressed in the human endocervix throughout the menstrual cycle. Fertil Steril 1997;67:636-640

33. Mularoni A, Adessi GL, Arbez-Gindre F, Agnani G, Nicollier M. 
Competitive RT-PCR to quantify CFTR mRNA in human endometrium. Clin Chem 1996;42:1765-1769.

34. Hincke MT, Nairn AC, Staines WA. Cystic fibrosis transmembrane conductance regulator is found within brain ventricular epithelium and choroid plexus. J Neurochem 1995;64:1662-1668.

35. Mulberg AE, Wiedner EB, Bao X, Marshall J, Jefferson DM, Altschuler SM. Cystic fibrosis transmembrane conductance regulator protein expression in brain. Neuroreport 1994;5: 1684-1688.

36. Tousson A, Van Tine BA, Naren AP, Shaw GM, Schwiebert LM. Characterization of CFTR expression and chloride channel activity in human endothelia. Am J Physiol 1998;275:C1555-C1564.

37. Tran-Paterson R, Davin D, Krauss RD, Rado TA, Miller DM. Expression and regulation of the cystic fibrosis gene during rat liver regeneration. Am J Physiol 1992;263:C55-C60.

38. Wells RG, Hediger MA. Cloning of a rat kidney cDNA that stimulates dibasic and neutral amino acid transport and has sequence similarity to glucosidases. Proc Natl Acad Sci U S A 1992;89: 5596-5600.
39. Bertran J, Werner A, Moore ML, Stange G, Markovich D, Biber J, Testar X, Zorzano A, Palacin M, Murer H. Expression cloning of a cDNA from rabbit kidney cortex that induces a single transport system for cystine and dibasic and neutral amino acids. Proc Nat Acad Sci U S A 1992;89:5601-5605.

Received December 15, 1999. Accepted August 16, 2000.

Address requests for reprints to: Arthur L. Finn, M.D., Department of Medicine, CB \#7155, UNC/Chapel Hill School of Medicine, Chapel Hill, North Carolina 27599-7155. e-mail: afinn@med.unc.edu; fax: (919) 966-4251.

Supported by Cystic Fibrosis Foundation grant G777 (to A.L.F.) and National Institutes of Health grant NS18788 (to G.S.O.).

The authors thank William S. Lane and John M. Neveu of the Harvard Microchemistry Facility for expertise in the high-performance liquid chromatography, mass spectrometry, and peptide sequencing. 